\title{
The Three-Dimensional Case Disposition in the Philippine Justice System: An Interface
}

\author{
Mario A. Garcia \\ Kalinga State University \\ Tabuk City, Kalinga \\ Philippines
}

\begin{abstract}
This research intends to look into the performance of the three levels of Justice Processes in the Philippines taking Tabuk City, Kalinga as the model. As a result of the study, it reveals that the first level system the Barangay Justice performs better than the regular court in terms of settling disputes and maintaining peace to the community. It was also revealed that the Indigenous justice processes of Kalinga known as the "Bodong" performs more than enough in settling disputes since it covers all crimes provided the parties thereto decided to settle it through the intervention of the tribal larders "pangat", its resolution is recognized by the regular court as a jurisprudence. Hence, it shows that the effect of mediation, conciliation and arbitration are deemed more effective because it does not only settle dispute but it carries with it a restorative effect towards the parties. In these systems, resolution is easily attained due to the voluntary nature on the part of the parties to settle their differences without any further cost. Under these circumstances, its effect to the community is more understanding and consideration.
\end{abstract}

Keywords: Barangay Justice System, the regular court, indigenous Kalinga Pagta, Mataguan Bodong Consultative Council, jurisdictions

\section{Introduction}

Justice system in whatever form has only one end in view and that is to attain justice on both parties involved whether on personal level to institutional level. Another objective of justice system is to avert the act of others to the disadvantage of another where there will be injustices that may cause change in a person or even the entire community behavior just to protect their welfare and interest. The instrument of the justice system is no less than the court that is armed with ethical standards of fairness and out of biases. Hence, in the Philippine setting, there are three forms of court which the laws and constitution recognized.

1.1. First level court is at the Barangay level as given authority by the local government code (RA 7610) and PD 1508 which create the office of the katarungangpambarangay manned by the Lupongtagapamayapa and lupongtagapagkasundo with an end in view of settling disputes at the barangay level. The main guide of the barangay justice is derived from the concept of the Alternative Dispute Resolution (ADR) law, RA 9285. Per legal opinion of Atty. Persida Acosta in Pang-et vs. Manacnes (G.R. No. 167261, March 2, 2007), that: "What is compulsory under the Katarungang Pambarangay Law is that there be a confrontation between the parties before the Lupon Chairman or the Pangkat and that a certification be issued that no conciliation or settlement has been reached, as attested to by the Lupon or Pangkat Chairman, before a case falling within the authority of the Lupon may be instituted in court or any other government office for adjudication. In other words, the only necessary pre-condition before any case falling within the authority of the Lupon or the Pangkat may be filed before a court is that there has been personal confrontation between the parties but despite earnest efforts to conciliate, there was a failure to amicably settle the dispute.

1.2. The second level court is called the Regular Court as the third pillar of the criminal justice system. The regular court is the arm of the formal government tasked to conduct check and balance between parties of a dispute. Since the regular court is a statutory agency, it is strictly guided by the rules of court where the civil procedures are designed to settle civil disputes and the criminal procedures designed to address problems of civil, criminal and all other matters which creates disputes. The tendency of the regular court by following its court procedures makes the case tedious to the agony of the parties. Taking a case decided by the Municipal Trial Court, San Felipe, Zambales (MTC), in February 4, 2009. In the case of PEOPLE OF THE PHILIPPINES, thru Private Complainant BRIAN VICTOR BRITCHFORD, Petitioner vs. SALVADOR ALAPAN, Respondent. The final decision comes only in January 10, 2018 where the supreme courts presided by Chief Justice Maraia Lourdes Serono states its decision Indeed, Administrative Circular No. 13-2001 provides that "should only a fine be imposed and the accused be unable to pay the fine, there is no legal obstacle to the application of the Revised Penal Code provisions on subsidiary imprisonment." 
However, the Circular does not sanction indiscriminate imposition of subsidiary imprisonment for the same must still comply with law. ......There is no doubt that the MTC decision has long attained finality and that none of the aforementioned exceptions finds application in this case. Hence, the MTC decision stands and any other question involving the said decision must now be put to rest.

1.3. By virtue of the Indigenous Peoples Right Act (IPRA) (RA8371), the government formally recognized the different tribal justices system countrywide where the "Kalinga Bodong" is one of those tribal justice systems duly recognized which pushed to the codification of the "PAGTA" law of the Bodong.Subsequently, to fully realize the objectives of the "PAGTA", the Mataguan Bodong Consultative Council (MBCC) was organized as an implementing agency of the Pagta.

In connection hereof, Velcado et.al. (2015) states that the Kalingas decided to institutionalize the practice of bodong so that the provisions as well as polices would become binding. Consequently, bodong holders, binodngans and the local government authorities created the Matagoan Bodong Consultative Council. The seat is located in Tabuk, Kalinga, the capital town (now a city) of the province. The institutionalization of bodong, which is practiced by the Matagoan Bodong Consultative Council (MBCC) through Executive Order 2011-01 issued by the city mayor of Tabuk, formalized the merging of the Municipal Bodong Council and Matagoan Consultative Body into one. With these setups, in kalinga, these three forms of courts are working hand in hand with one end in view and that is for the realization of a Peaceful Community to live in.

The setting of the study is in the City of Tabuk, Kalinga where the indigenous practices of the Bodong was made formal by virtue of the codification of the Pagta and the establishment of the Matagoan Bodong Consultative Council (MBCC) as the implementing arm of the Bodong.

\section{Objectives}

The objective of this study is to assess the number of filed cases and status of disposition of cases in the following three types of court in the City of Tabuk, Kalinga.

a. Barangay court (at least two main Barangay from Dagupan and Bulanao)

b. Regular court

- MTC

c. The Bodong through its implementing agency the MBCC

\section{Scope and Delimitation}

The study focuses only on the assessment as to;

1.Number of cases filed, and

2. Case status whether convicted, dismissed, amicably settled or ongoing

As to place and Agency;

1. Two Barangays, one from Bulanao and one from Dagupan

2. The regular court which includes; the City Court of Tabuk

3. MataguanBodong Consultative Council

\section{Conceptual Framework}

This research is drawn from the concept that in the resolution of disputes, parties always take into consideration what is best for the Availment of justice on an issue. Different advocates are working overtime in trying to establish rules and precedence as an instrument of just and fair resolution of disputes. No less than the church, Peoples organizations and other non-government organizations and civic minded groups are all advocating for simplified and reliable justice processes.

\section{Methodology}

This is a qualitative research through document scrutiny and interview to the following offices:

1. Barangay

a. Barangay Bulanao Centro

b. Barangay Dagupan Centro

2. City Court located at Dagupan, Tabuk City

3. MataguanBodong Consultative Council (Tabuk City Hall)

Data gathered were consolidated and vertically compared for analytical evaluation. 
Statistical tool used is simple percentage/average to determine the status and actions done on the cases filed in each of the courts.

\section{Results and Discussion}

Court Processes/Procedures: procedures considered are those that involve general rules in criminal actions.

\subsection{The Barangay Court}

Jurisdiction. PD 1508, Section 2. Subject matters for amicable settlement. The Lupon of each barangay shall have authority to bring together the parties actually residing in the same city or municipality for amicable settlement of all disputes except:

1. Where on party is the government, or any subdivision or instrumentality thereof;

2. Where one party is a public officer or employee, and the dispute relates to the performance of his official functions;

3. Offenses punishable by imprisonment exceeding 30 days, or a fine exceeding P200.00;

4. Offenses where there is no private offended party;

5. Such other classes of disputes which the Prime Minister may in the interest of justice determine upon recommendation of the Minister of Justice and the Minister of Local Government.

Processes:PD 1508, Section 4. Procedure for amicable settlement.

a) Who may initiate proceedings. Any individual who has a cause of action against another individual involving any matter within the authority of the Lupon as provided in Section 2 may complain orally or in writing, to the Barangay Captain of the barangay referred to in Section 3 hereof.

b) Mediation by Barangay Captain. Upon receipt of the complaint, the Barangay Captain shall, within the next working day summon the respondent/s with notice to the complainant/s for them and their witnesses to appear before him for a mediation of their conflicting interests. If he fails in his effort within fifteen (15) days from the first meeting of the parties before him, he shall forthwith set a date for the constitution of the Pangkat in accordance with the provisions of Section 1 of this Decree.

c) Hearing before the Pangkat. The Pangkat shall convene not later than three (3) days from its constitution, on the day and hour set by the Barangay Captain, to hear both parties and their witnesses, simplify issues, and explores all possibilities for amicable settlement. For this purpose, the Pangkat may issue summons for the personal appearance of parties and witnesses before it. In the event that the party moves to disqualify any member of the Pangkat by reason of relationship, bias, interest or any other similar ground/s discovered after constitution of the Pangkat, the matter shall be resolved by the affirmative vote of the majority of the Pangkat whose decision shall be final. Should disqualification be decided upon, the procedure provided for in paragraph $(\mathrm{g})$ of Section 1 shall be followed.

d) Sanctions. Refusal or willful failure of any party or witness to appear in compliance with the summons issued pursuant to the preceding two (2) paragraphs may be punished by the city or municipal court as for direct contempt of court upon application filed therewith by the Lupon Chairman, the Pangkat Chairman, or by any of the parties. Further, such refusal or willful failure to appear shall be reflected in the records of the Lupon Secretary or in the minutes of the Pangkat Secretary and shall bar the complainant from seeking judicial recourse for the same cause of action, and the respondent, from filing any counterclaim arising out of or necessarily connected therewith.Willful failure or refusal without justifiable cause on the part of any Pangkat member to act as such, as determined by the vote of a majority of all the other members of the Lupon, whose decision thereon shall be final, shall result in his disqualification from public office in the city or municipality for a period of one year.

e) Time limit. The Pangkat shall arrive at a settlement/resolution of the dispute within fifteen (15) days from the day it convenes in accordance with paragraph (c) hereof. This period shall, at the discretion of the Pangkat, be extendible for another period which shall not exceed fifteen (15) days except in clearly meritorious cases.

\subsection{The regular Court}

Jurisdiction: the general rule states, sec. 15, Rule 110, Rules of court, 2005. Place where action is to be instituted. a. Subject to existing laws, the criminal action shall be instituted and tried in the court of the municipality or territory where the offense was committed or where any of its essential ingredients occurred.

\subsubsection{Municipal Trial Courts (MTC)}

a. Its exclusive Jurisdiction

1. All violations of city or municipal ordinances committed within their respective territorial jurisdictions. 
2. All offenses punishable with an imprisonment of not more than six (6) years irrespective of the amount of fine and in all cases of damages to property through criminal negligence, regardless of other penalties and civil liabilities arising there from, all offenses committed by public officers and employees (except violation of RA 1379 and articles 210-212 of the Revised penal Code) in relation to their offices including those employed in the government owned and controlled corporations and by private individuals charged as co-principal, accomplices, accessories, punishable with an imprisonment of not more than six (6) years.

b. Summary procedures on traffic violations, violations of the rental law, violations of city or municipal ordinances. And all other offenses where the penalty does not exceed six(6) months imprisonment and or an amount of $\mathrm{PhP}$ $1,000.00$ fine, irrespective of other penalties or civil liabilities arising there from, and in offenses involving damage to property through criminal negligence where the impossible fine does not exceed $\mathrm{PhP} 10,000.00$.

\subsection{The MBCC}

Its Role: The role of the MBCC is the peace core that initiates and formulates policies/rules regarding tribal disputes/conflicts as an avenue for the non-tribal groups in making rules/laws concerning peace and order, to recommend programs for ethnic, cultural and social integration of Tabuk society.

Power and Functions:

1. The MBCC shall be the implementing arm of the Matagoan Peace and Order Council in pursuing the programs and activities concerning peace and order;

2. To formulate a proto-pagta to be implemented in the city of Tabuk;

3. To promulgate provisions to be implemented in the Matagoan Area;

4. To remind all Bodong Holders of their duties and responsibilities;

5. It shall be responsible in conciliating, mediating conflict brought through before it emanating from inter-tribal, intra-tribal problems between binodngans and non-binodngans or among binodngans for as long as parties interest agree;

6. Initiate resolutions of boundary disputes/bogis between sub-tribes;

7. Advocates of peace and order;

8. Perform such other functions as may be assigned to it from time to time.

Filing of cases:

Cases are to be filed in the court, Barangay or to the Bodong Holders as the case may be. The MBCC will only acquire jurisdiction over a case when;

1. The Barangay captain endorses it;

2. The Barangay captain requests for its assistance, or

3. The Bodong Holders endorse it or requests for assistance.

\section{Results and Discussion}

\subsection{CASE Disposal Performance at the Barangay Court}

\section{Findings:}

7.1.1. Barangay Centro of DagupanTabuk deserves its awards as two times outstanding Lupong Tagapaya and a National Awardee LupongTagapayapa for the years 2011 to 2012. Basing from its performance of one hundred percent amicable settlement is a mantle of efficiency of the Barangay officials that is worth emulating. These performances manifest prudence and diligence on the part of the Barangay officials. It also manifests the full trust and confidence of the community towards the Barangay officials. It was noted that the approach of settlement observed are very basic, there are no complicated rules; when there is a complaint, immediately, the parties are called together for confrontation and intervention. Both parties are given time to air their sides and after which the chairman asked them what they want, both parties again proposed what they think they deserve. If there is a disagreement the chairman allows them for a private consultation with their relatives, after which they meet again and commonly immediately come to terms which leads to closing of the case. It is also observed that after resolution of the case, their relationships were immediately restored. The Barangay is like other Barangays with aggregate population of diverse tribes and Nationalities. It is the center of commerce in the city where majority of the population are transient, that after having transacted business, they went back home to their places. Good Neighborhood relationships are observed to be the key of easily resolving conflicts. Though aggregate in kinship, mutual understanding and consideration to the welfare and interest of the neighborhood is very strong which makes resolution of disputes makes it easier. 
7.1.2. Barangay Bulanao Centro is the fastest growing center of development of the city. Hence, an aggregate of population is slowly creeping exponentially. Commercial establishments are at its fastest pace of growth.

It is not remote therefore that in a year, the average cases filed at the barangay level is almost a hundred. But the rate of settlement runs at an average of at least eighty two percent (82\%) a performance reflective of the trust and confidence of the community towards the Barangay leadership. But since it is the center of development and the increase of population cannot be avoided, some cases filed where parties involved are of different origin, there are times that amicable settlement is difficult to reach hence an average of $5.8 \%$ endorsement to the court of unsettled cases is unavoidable.

Other comments:

1. Barangay Centro in Dagupan was awarded Two times Regional (CAR) awardees for outstanding lupongtagapayapa for 2011 and 2012, and

2. A National awardee 2012, Lupong Tagapayapa Awards

3. Barangay Centro of Bulanao is the center of on-going development and it is the site of the Provincial Government offices

\subsection{Case Disposal Performance of the City Court, Tabuk City}

\section{Findings:}

On the data above covering at least three years 2011 to 2013. The performance of the city court is most effective at amicably settling disputes with a three years average performance of 39.47 percent, with case dismissal on the merits at 17.98 percent average. Its conviction rate stands at 11.84 percent with acquittal rate of 1.75 percent, the remaining other cases are either archived or still in progress. This performance rating stems from several factors; as to its settling of disputes, parties of the case commonly settle their disagreement after the judge initially consulted with both parties and explained to them the social and economic impact of a prolonged dispute in court. Dismissal on the merits also stems from other factors like unwarranted filing of case and others which include non-interest and withdrawal of complaint. Overall, this first level court is most effective in terms of letting parties in dispute realize the intricacies of abhorring grudge with somebody in the community, hence decide to settle it to regain peace in between them. Notably, the judge who is a native Kalinga has established a reputation where people in the city and the province are interested to listen and seek advices whenever confronted with problems. His techniques are quite simple integrating common cultural practices and also restorative approaches that will not only make disputing parties come to their right senses but at most, makes them feel comfortable with each other after some sort of conference. At the end, the disputing parties make amends and settle their disputes without any reservations. The conviction rate at 11.84 percent is the result of an extensive and rigorous scrutiny whenever the parties in dispute cannot make amends where the degree of offense is somewhat obviously detrimental to public welfare and that the offender may have exhibited behavior that is unfavorable to the taste of public interest.

Other comments:

The city court is handled by only one judge who covered also at least 4 other circuit court.

\subsection{Case Disposal Performance at the MBCC}

\section{Findings:}

The city of Tabuk being the center of commerce and governance, its strong stance for peaceful environment is so apparent which lead to its proclamation as the Matagoan Zone or center/zone of peace. Noting that Tabuk is within Kalinga where the practice of Bodong is ingrained with the people, it is therefore one of its mandate to uphold the tribal practices as one means of serving justice within the city, hence the establishment of the MBCC. The MBCC, being a special court admits an average 44 of filed cases per year. Its performance of settling cases runs at an average of $65 \%$ which is also acceptably high. Its backlog of cases is at an average of $25 \%$ as a result of the difficulty in making the parties come to terms specially when parties in disputes involves tribes that are known to be so demanding beyond what the settled rule of penalties under the PAGTA. On nine (9) occasions, the cases were forwarded to the court for proper determination and disposition since due to the non-agreement of the parties involved in settling their dispute amicably. On one instance, one case was remanded back to the Bodong holders of the disputing parties because of some reasons where one party of the dispute do not submit to the terms and conditions prescribed by the common rules proposed during the settlement. The MBCC being a special court appears to be an instrument and implementing arm of the Alternative Dispute Resolution system. Alternative since it operates outside the regular judicial system and outside the Barangay Justice System. It has its own rules emanating from sub-cultural practices collated in one. The rules are simply developed from the concept of restorative justice for its end objective is to resolve and restore differences from disputing parties especially of tribal nature. 


\subsubsection{Status of other cases not covered by the rules of the MBCC;}

In 2011: (5 cases)

1 case was dropped due to non interest of complainant

2 case elevated to court

1 case referred back to Bodong holders

1 case withdrawn by complainant

In 2012 (9 cases)

7 cases elevated to court

2 cases dropped due to non interest of complainant

\section{Conclusions}

On the foregoing, it is concluded that the more complex the rules the more difficult to settle disputes. The simpler the rules, the easier to come up with settlements. The MTC manned by a learned legal practitioner, its output in terms of settlement is outnumbered by the output of the Barangay and the special court the MBCC. The regular court appears to be a court for those who have money who can endure a lengthy and expensive litigation where those who cannot afford are inclined to be convicted. The effect of mediation, conciliation and arbitration are deemed more effective because it does not only settle dispute but it carries with it a restorative effect towards the parties. In these systems, resolution is easily attained due to the voluntary nature on the part of the parties to settle their differences without any further cost. Under these circumstances, its effect to the community is more understanding and consideration. The rule of Alternative Dispute Resolution is carried out through the MBCC as a special body constituted to hear and settle disputes outside the adjudicatory rules of court. Its decision does not only affect the interest of the direct parties but extends to their entire tribes that may restrain any further misunderstanding from the whole tribal community.

\section{Recommendations}

Drawn from the conclusions, the following recommendations are forwarded; In the regular court system, the retributive and penal rules are discourage and the restorative concept be strengthen to promote an equitable opportunity to gain justice. Simplify the processes to afford speedy resolutions of disputes. The barangay justice system and special bodies be further strengthened by provisions of special training and assistance in terms of facilities to accommodate more dispute resolutions. It is not however recommended for monetary compensations because it will later become an avenue for corruption and ill practice. For just and equitable justice, court litigations and quasi court hearings be spared from too much expenses such that true justice be afforded to all parties involved.

\section{Tables}

Table I: Case Disposal Performance of Barangay Dagupan Centro

\begin{tabular}{|c|c|c|c|c|c|c|c|c|}
\hline \multirow{3}{*}{\multicolumn{2}{|c|}{$\begin{array}{l}\text { No. of cases } \\
\text { filed }\end{array}$}} & \multicolumn{7}{|c|}{ Case Status } \\
\hline & & \multirow[t]{2}{*}{ Convicted } & \multirow[t]{2}{*}{ Acquitted } & \multicolumn{3}{|l|}{ Dismissed } & \multirow[t]{2}{*}{ Archived } & \multirow{2}{*}{$\begin{array}{l}\text { On } \\
\text { going }\end{array}$} \\
\hline & & & & On the merits & \multicolumn{2}{|c|}{ Amicably settled } & & \\
\hline 2011 & 33 & & & & 33 & $100 \%$ & & \\
\hline 2012 & 60 & & & & 60 & $100 \%$ & & \\
\hline 2013 & 55 & & & & 55 & $100 \%$ & & \\
\hline Total & 148 & & & & 148 & $100 \%$ & & \\
\hline
\end{tabular}

Table II: Case Disposal Performance of Barangay, Bulanao Centro

\begin{tabular}{|c|c|c|c|c|c|c|c|c|c|c|c|}
\hline \multirow{3}{*}{\multicolumn{2}{|c|}{$\begin{array}{l}\text { No. of cases } \\
\text { filed }\end{array}$}} & \multicolumn{10}{|c|}{ Case Status } \\
\hline & & \multirow[t]{3}{*}{ Convicted } & \multirow[t]{3}{*}{ Acquitted } & \multicolumn{4}{|c|}{ Dismissed } & \multirow{2}{*}{\multicolumn{2}{|c|}{ Ongoing }} & \multirow{2}{*}{\multicolumn{2}{|c|}{ endorsed }} \\
\hline & & & & \multicolumn{2}{|c|}{ On the merits } & \multicolumn{2}{|c|}{$\begin{array}{l}\text { Amicably } \\
\text { settled }\end{array}$} & & & & \\
\hline 2011 & 80 & & & 1 & $1.25 \%$ & 75 & $94 \%$ & & & 4 & $5 \%$ \\
\hline 2012 & 56 & & & 1 & $1.78 \%$ & 50 & $89 \%$ & & & 4 & $7.14 \%$ \\
\hline 2013 & 80 & & & 6 & $7.5 \%$ & 51 & $62 \%$ & 15 & $18.75 \%$ & & \\
\hline Total & 216 & & & 8 & $1.03 \%$ & 176 & $82 \%$ & & & & $5.8 \%$ \\
\hline
\end{tabular}


Table III: Case Disposal Performance of the City Court, Tabuk City

\begin{tabular}{|c|c|c|c|c|c|c|c|c|c|c|c|c|c|}
\hline \multirow{3}{*}{\multicolumn{2}{|c|}{$\begin{array}{l}\text { No. of } \\
\text { cases filed }\end{array}$}} & \multicolumn{12}{|c|}{ Case Status } \\
\hline & & \multirow{2}{*}{\multicolumn{2}{|c|}{ Convicted }} & \multirow{2}{*}{\multicolumn{2}{|c|}{ Acquitted }} & \multicolumn{4}{|c|}{ Dismissed } & \multirow{2}{*}{\multicolumn{2}{|c|}{ Archived }} & \multirow{2}{*}{\multicolumn{2}{|c|}{ On going }} \\
\hline & & & & & & \multicolumn{2}{|c|}{ on the merits } & \multicolumn{2}{|c|}{$\begin{array}{l}\text { Amicably } \\
\text { settled }\end{array}$} & & & & \\
\hline 2011 & 70 & 10 & $14.28 \%$ & 1 & $1.4 \%$ & 15 & $21.42 \%$ & 27 & $38.57 \%$ & 2 & $2.8 \%$ & 15 & $21.42 \%$ \\
\hline 2012 & 61 & 4 & $6.5 \%$ & 2 & $3.28 \%$ & 16 & $26.29 \%$ & 31 & $50.81 \%$ & 2 & $3.28 \%$ & 6 & $9.83 \%$ \\
\hline 2013 & 97 & 13 & $13.49 \%$ & 1 & $1.11 \%$ & 10 & $11.11 \%$ & 32 & $32.98 \%$ & 4 & $4.12 \%$ & 37 & $38.14 \%$ \\
\hline Total & 228 & 27 & $11.84 \%$ & 4 & $1.75 \%$ & 41 & $17.98 \%$ & 90 & $39.47 \%$ & 8 & $3.5 \%$ & 58 & $25.45 \%$ \\
\hline
\end{tabular}

Table IV: Case Disposal Performance of the MBCC

\begin{tabular}{|c|c|c|c|c|c|c|c|c|c|}
\hline \multirow{3}{*}{$\begin{array}{l}\text { No. } \\
\text { filed }\end{array}$} & \multirow{3}{*}{ of cases } & \multicolumn{8}{|c|}{ Case Status } \\
\hline & & \multirow{2}{*}{ Convicted } & \multirow{2}{*}{ Acquitted } & \multicolumn{3}{|l|}{ Dismissed } & \multirow[t]{2}{*}{ Archived } & \multirow{2}{*}{\multicolumn{2}{|c|}{ On going }} \\
\hline & & & & $\begin{array}{l}\text { On the } \\
\text { merits }\end{array}$ & \multicolumn{2}{|c|}{ Amicably settled } & & & \\
\hline 2011 & 48 & & & & 31 & $64.58 \%$ & & 12 & $25 \%$ \\
\hline 2012 & 37 & & & & 23 & $62.16 \%$ & & 5 & $13.5 \%$ \\
\hline 2013 & 46 & & & & 31 & $67.39 \%$ & & 15 & $32.6 \%$ \\
\hline Total & 131 & & & & 85 & $64.88 \%$ & & 32 & $24.42 \%$ \\
\hline
\end{tabular}

\section{References}

PD 1508,(June 11, 1978), ESTABLISHING A SYSTEM OF AMICABLY SETTLING DISPUTES AT THE BARANGAY LEVEL,

RA 7610, BOOK III,(October 10, 1991), LOCAL GOVERNMENT UNITS [Sections 384 to 510), PAGTA (law of the Bodong)(April 27, 2002) as amended at Luplupa, Tinglayan, Kalinga,.

REPUBLIC ACT NO. 8371, (October 29, 1997),AN ACT TO RECOGNIZE, PROTECT AND PROMOTE

THE RIGHTS OF INDIGENOUS CULTURAL COMMUNITIES/ INDIGENOUS PEOPLES, CREATING A NATIONAL COMMISSION ON INDIGENOUS PEOPLES, ESTABLISHING IMPLEMENTING MECHANISMS, APPROPRIATING FUNDS THEREFOR, AND FOR OTHER PURPOSES. Republic Act No. 9285, (April 2, 2004), AN ACT TO INSTITUTIONALIZE THE USE OF

AN ALTERNATIVE DISPUTE RESOLUTION SYSTEM IN THE PHILIPPINES AND TO ESTABLISH THE OFFICE FOR ALTERNATIVE DISPUTE RESOLUTION, AND FOR OTHER PURPOSES

REPUBLIC ACT NO. 876, (April 2, 2004), AN ACT TO AUTHORIZE THE MAKING OFARBITRATION AND SUBMISSION AGREEMENTS, TO PROVIDE FOR THE APPOINTMENT OF ARBITRATORS AND THE PROCEDURE FOR ARBITRATION IN CIVIL CONTROVERSIES, AND FOR OTHER PURPOSES

Atty. Persida Acosta, (July 6, 2016), "Barangay Conciliation must before filling a case" Manila Times, April 24, 2019.

G.R. No. 199527, (2018), PEOPLE OF THE PHILIPPINES, thru Private Complainant BRIAN

VICTOR BRITCHFORD, Petitioner vs. SALVADOR ALAPAN, Respondent. LawPhil data bank.

Vecaldo, Clemente, Tamangen, (2015), Effectiveness of Bodong as an Alternative Dispute

Resolution: A Glimpse of Kalingas' Peace Framework, Philippines: Horizon Research Publishing. Retrieved from www.hrpub.org/download/20150301/SA1-10490125 